\title{
Correlation of anti-wrinkling and free radical antioxidant activities of Areca nut with phenolic and flavonoid contents
}

\author{
Na-young BYUN ${ }^{1 *}$, Mi-Ra HEO ${ }^{2 ¥}$, Soon-Ho YIM ${ }^{1 \star}$ (])
}

\begin{abstract}
This study was conducted to compare the correlations between free radical antioxidant activity and anti-wrinkling activity. Areca nut was extracted using various concentrations of ethanol $(0,40,80$, and $100 \%)$ and methanol $(0,40,80$, and $100 \%)$ at $100{ }^{\circ} \mathrm{C}$ for $90 \mathrm{~min}$. The ethanolic and methanolic extracts of Areca nut were evaluated for total phenolic content (TPC), total flavonoid content (TFC), antioxidant activity, including total antioxidant capacity (TAC), FRAP, DPPH, ABTS, and superoxide anion radical scavenging activity (SRSA), and anti-wrinkling activity (collagenase inhibition and elastase inhibition). In addition, the antioxidant activities were correlated with collagenase inhibition. The antioxidant activities of the extracts exhibited little correlation $(R=0.008-0.0760)$ with TPC, TFC, and TAC; however, significant correlation $(\mathrm{R}=0.825-0.891)$ was shown with collagenase inhibition. The $40 \%$ and $80 \% \mathrm{EtOH}$ extracts showed the highest levels of antioxidant activities, and also had the highest phenolic and flavonoid contents. The antioxidant activities of the $80 \% \mathrm{EtOH}$ extracts was greater than that of other extracts. These results indicate that the collagenase inhibition effects of Areca nut extracts may be due to free radical antioxidant activities, and the optimal extraction condition was $80 \% \mathrm{EtOH}$.
\end{abstract}

Keywords: Areca nut; free radical antioxidant; anti-wrinkling, RNS.

Practical Application: Research about antioxidant activities, anti-wrinkling functional products of Areca nut.

\section{Introduction}

Free radicals, including reactive oxygen species (ROS) and reactive nitrogen species (RNS) are molecules that have unpaired electrons. They are generally unstable and damage normal cells in the body (Kim et al., 2018). These free radicals can be produced by environmental pollution, chemicals, UV rays, and stress in living organisms (Figure 1). When a certain amount of ROS and RNS are produced in the body, they are removed by antioxidant mechanisms of endogenous antioxidant enzymes, such as catalase (CAT), glutathione peroxidase (GSH-Px), and superoxide dismutase (SOD) (Choi et al., 2004; Park et al., 2017). However, excessive amounts of ROS (hydrogen peroxide $\mathrm{H}_{2} \mathrm{O}_{2}$, superoxide anion $\mathrm{O}_{2}^{-}$, and hydroxyl radicals $\mathrm{OH}$ ) and RNS (peroxynitrite $\mathrm{ONOO}^{-}$and nitroxyl anion NO.) produced by cellular metabolism may attack biological tissues and damage cells during various metabolic processes (Yun et al., 2018; Lee \& Im, 2012). ROS and RNS have been reported to cause oxidative stress on proteins and DNA in cells that can lead to cell damage, and may contribute to degenerative diseases, such as meningitis, Alzheimer's disease and Parkinson's disease (Yun et al., 2018; Lee \& Im 2012). In addition, they are involved in promoting melanin production by destroying and damaging the skin's antioxidant defense network, which can lead to accelerated skin aging, such as wrinkle formation, elasticity reduction, freckles, and spotting (Go et al., 2020).
The safety problems related to synthetic antioxidants (BHA, BHT, and others) have led to an increased interest in the development of safe and inexpensive natural-product antioxidants (Park \& Kim, 2008). The polyphenols and flavonoids of natural antioxidants are known to possess strong antioxidant activities, and have the ability to scavenge ROS, RNS, and free radicals. Moreover, several studies have reported a correlation between the increased dietary intake of natural antioxidants and a reduction in coronary heart disease, reduced cancer mortality, anti-aging, and longer life extension (Cho et al., 2016).

Areca nut is the seed of the fruit of Areca catechu LINNE (Palmae), and has been used as a therapeutic and in various natural dyestuffs in Malaysia and China for many years. It is mainly produced in Southeast Asia, South China, India, Taiwan, the Philippines and East Africa (Lee et al., 2001). This plant has been reported to contain bioactive compounds, such as alkaloid components (arecoline, arecolidine, and guvacoline), steroid components (diosgenin, kryptogenin, sitosterol), and tannic components (catechin and epicatechin). Additionally, it is known to have gastrointestinal protection, insecticidal, and antifungal effects. Recently, it has also been reported to have anti-cancer, thrombosis prevention, and tyrosinase enzyme activity inhibition effects (Chin \& Cho, 2007; Lee et al., 2001). 




Figure 1. Mechanisms of reactive oxygen species produced in mitochondria.

The objective of this study was to determine the antioxidant abilities of Areca nut extracts using total phenolic content (TPC), total flavonoid content (TFC), total antioxidant capacity (TAC), DPPH, ABTS, FRAP, and superoxide anion radical scavenging. In addition, the antioxidant activities were correlated with NO, $\mathrm{ONOO}^{-}$and skin aging (collagenase inhibition and elastase inhibition) including TPC, TFC, and TAC.

\section{Materials and methods}

\subsection{Experimental materials}

Folin-Ciocalteu reagent, ABTS (2,2'-azino-bis-3ethylbenzothiazoline-6-sulfonic acid), DPPH (1,1-diphenyl2-picrylhydrazyl), L-ascorbic acid, and Trolox were obtained from Sigma-Aldrich (St. Louis, MO, USA). Other extraction solvents and reagents used were of premium grade.

\subsection{Sample extraction}

The Areca nuts used in this study were purchased from Art\&crafts (Goyang, Korea), grown in Malaysia in 2019, and used after grinding in a grinder (NFM-3561SN, NUC Co, Daegu, Korea). In preliminary experiments, extraction solvents with an excellent extraction efficiency in plants were determined, and the extraction conditions of Areca nuts according to the concentration of each solvent were selected. Distilled water $(100 \mathrm{~mL})$, and either $40 \%$ ethanol, $80 \%$ ethanol, $100 \%$ ethanol, $40 \%$ methanol, $80 \%$ methanol, or $100 \%$ methanol were added to $10 \mathrm{~g}$ of ground Areca nut, followed by reflux extraction at $100{ }^{\circ} \mathrm{C}$ for $1 \mathrm{~h}$. Samples were filtered through $185 \mathrm{~mm}$ filter paper, and the filtrate was concentrated using an ultra-fastvacuum, low-temperature concentrator (COSMOS660-50L, Kyungseo Machines Co, Incheon, Korea). The concentrated samples were transferred to vials and stored at $4{ }^{\circ} \mathrm{C}$ for use in later experiments.

\subsection{Total Phenolic and Total Flavonoid Contents (TPC, TFC)}

The total polyphenol content was measured using the Folin-Ciocalteu colorimetric method (Yun et al., 2018; Wabaidur et al., 2020), with tannic acid as a standard solution. A total of $500 \mu \mathrm{L}$ of Folin reagent was added to $500 \mu \mathrm{L}$ of each sample and incubated at room temperature for $3 \mathrm{~min}$. Then, after adding $500 \mu \mathrm{L}$ of $10 \% \mathrm{Na}_{2} \mathrm{CO}_{3}$ the light was blocked for $1 \mathrm{~h}$. Absorbance was measured at $760 \mathrm{~nm}$ using a spectrophotometer (Neogen Optizen 2120 UV, Sejong, Korea), then the absorbance was measured with a concentrationspecific amount of tannic acid. The quantitative value of TAE (tannic acid equivalent) per gram of extract was calculated according to the standard calibration curve $(y=0.0366 x+$ $0.0033, \mathrm{R}^{2}=0.9933$ ).

Total flavonoid content was measured using the aluminum chloride colorimetric assay, with catechin as a standard solution. A total of for $200 \mu \mathrm{L}$ of each sample was diluted in $800 \mu \mathrm{L}$ of $80 \%$ ethanol. Then, $60 \mu \mathrm{L}$ of $5 \% \mathrm{NaNO}_{2}$ was added, and the samples were incubated at room temperature for $5 \mathrm{~min}$. Further, $60 \mu \mathrm{L}$ of $10 \% \mathrm{AlCl}_{3}$ was added and samples were incubated for $5 \mathrm{~min}$. After $400 \mu \mathrm{L}$ of $1 \mathrm{~N} \mathrm{NaOH}$ was added, absorbance was measured at $415 \mathrm{~nm}$ using a spectrometer (Neogen Optizen 2120 UV, Sejong, Korea). The quantitative value of CE (Catechin equivalent) per gram of extract was calculated according to the standard calibration curve $(y=0.0025 x+0.0142, R 2=0.9992)$.

\subsection{Assay for the estimation of antioxidant activity}

\section{Phosphomolybdenum antioxidant assay (Total Antioxidant Capacity, TAC)}

Antioxidant capacities of curcumin, demethoxycurcumin and bisdemethoxycurcumin were evaluated by the method of Prieto et al. (1999). An aliquot of $0.1 \mathrm{~mL}$ of curcuminoids (equivalent to 50 and $100 \mathrm{ppm}$ ) was combined with $1.0 \mathrm{~mL}$ of reagent solution $(0.6 \mathrm{M}$ sulfuric acid, $20 \mathrm{mM}$ sodium 
phosphate and $4 \mathrm{mM}$ ammonium molybdate). Distilled water $(0.1 \mathrm{~mL})$ was used in place of the sample solution as a blank. The tubes were capped and incubated in a boiling water bath at $95^{\circ} \mathrm{C}$ for $90 \mathrm{~min}$. After the samples had cooled to room temperature, the absorbance of the aqueous solution was measured at $695 \mathrm{~nm}$ against a blank in a spectrophotometer (Neogen Optizen $2120 \mathrm{UV}$ ). According to the standard calibration curve $\left(y=0.0021 x-0.0165, R^{2}=0.9910\right)$ written with $\mathrm{L}$-ascorbic acid measured by concentration, quantitative values of AAE (ascorbic acid equivalent) per gram of extract were calculated.

\section{Ferric-Reducing Antioxidant Power (FRAP)}

The FRAP assay was done according to Benzie \& Strain (1996) with some modifications. The stock solutions included $300 \mathrm{mM}$ acetate buffer (pH 3.6), $10 \mathrm{mM}$ TPTZ (2, 4, 6- tripyridyls-triazine) in $40 \mathrm{mM} \mathrm{HCl}$, and $20 \mathrm{mM} \mathrm{FeCl}_{3} \cdot 6 \mathrm{H}_{2} \mathrm{O}$. A fresh working solution was prepared by mixing $25 \mathrm{~mL}$ acetate buffer, $2.5 \mathrm{~mL}$ TPTZ solution, and $2.5 \mathrm{~mL} \mathrm{FeCl}_{3} \cdot 6 \mathrm{H}_{2} \mathrm{O}$ solution, which was warmed to $37^{\circ} \mathrm{C}$ before use. Areca nut extract $(35 \mu \mathrm{L})$ was incubated with $1050 \mu \mathrm{L}$ of FRAP solution at $37^{\circ} \mathrm{C}$ degrees for $30 \mathrm{~min}$ in the dark. Readings of the colored product (ferrous tripyridyltriazine complex) were taken at $595 \mathrm{~nm}$. According to the standard calibration curve $(y=0.0014 x+0.0628$, $\left.\mathrm{R}^{2}=0.9997\right)$ written in Trolox measured by concentration, the quantitative values of TE (Trolox equivalent) per gram of extract were calculated.

\section{Peroxynitrite (ONOO-) scavenging activity}

$\mathrm{ONOO}^{-}$scavenging activity was detected by measuring the fluorescence emitted by oxidizing dihydrorhodamine 123 (DHR 123) (Kim et al., 2007). Five micromolar DHR 123 was made just prior to use. The buffer was prepared by mixing $50 \mathrm{mM}$ sodium phosphate, $90 \mathrm{mM}$ sodium chloride and $100 \mu \mathrm{M}$ DTPA with rhodamine buffer ( $\mathrm{pH}$ 7.4), and refrigerated before use. A total of $130 \mu \mathrm{L}$ of rhodamine buffer ( $\mathrm{pH} 7.4)$ was added to $10 \mu \mathrm{L}$ of sample, then $50 \mu \mathrm{L}$ of DHR 123 was added and mixed. Finally, $10 \mu \mathrm{L}$ of SIN-1 was added, and the samples were incubated at room temperature for $1 \mathrm{~h}$. ONOO- fluorescence intensity was measured at an excitation wavelength of $480 \mathrm{~nm}$ and an emission wavelength of $530 \mathrm{~nm}$ using a fluorescence microplate reader (SPECTRA MAX GEMINI EM, Molecular Devices Corp, USA). The ONOO- scavenging activity was calculated as follows: ONOO$^{-}$scavenging activity $(\%)=[1-(\mathrm{B} / \mathrm{A})] \times 100$ where $\mathrm{A}$ is the absorbance of the control and $\mathrm{B}$ is the absorbance of the test sample.

\subsection{Assay for the estimation of free radical}

\section{DPPH radical scavenging activity}

The effect of Areca nut on DPPH radicals was analyzed using a modified method of that described by Yamaguchi et al. (1998) (Yikmis, 2020). Briefly, $190 \mu \mathrm{L}$ of DPPH solution $(0.2 \mathrm{mM}$, 95\% methanol) was incubated with $10 \mu \mathrm{L}$ of extract. The reaction mixture was shaken well and incubated for $30 \mathrm{~min}$ at room temperature. The absorbance of the resulting solution was read at $517 \mathrm{~nm}$ against a blank. The radical scavenging activity was measured as a decrease in the absorbance of DPPH and calculated using the following equation: DPPH radical scavenging activity $(\%)=(\mathrm{A}-\mathrm{B}) / \mathrm{A} \times 100$ where $\mathrm{A}$ is the absorbance of the control and $\mathrm{B}$ is the absorbance of the test sample.

\section{ABTS radical scavenging activity}

The effects of Areca nut extracts on ABTS radicals were analyzed using a modified method previously described by Re et al. (1999). After mixing 7.4 mM ABTS and $2.45 \mathrm{mM}$ potassium persulfate solution at a ratio of $1: 1(\mathrm{v} / \mathrm{v})$, the samples were incubated for $24 \mathrm{~h}$ at $37^{\circ} \mathrm{C}$ to generate radicals. Absorbance was measured at $734 \mathrm{~nm}$. When the absorbance value of the working solution was $0.70 \pm 0.02$ at $734 \mathrm{~nm}$, it was used for the ABTS method. Briefly, $1350 \mu \mathrm{L}$ of ABTS solution was incubated with $150 \mu \mathrm{L}$ of extract. L-ascorbic acid was used as a control, and all experiments were repeated three times. ABTS radical scavenging activity was calculated using the following equation: ABTS radical scavenging activity $(\%)=(\mathrm{A}-\mathrm{B}) / \mathrm{A} \times 100$ where $A$ is the absorbance of the control and $B$ is the absorbance of the test sample.

\section{Superoxide anion radical scavenging activity (SRSA)}

Superoxide anion radical scavenging activity was measured by the nitroblue tetrazolium (NBT) reduction method using the experimental method of Fridovich (1970). After adding $40 \mu \mathrm{L}$ of $0.1 \mathrm{M}$ phosphate buffer ( $\mathrm{pH} 8.0), 100 \mu \mathrm{L}$ of 0.05 units $/ \mathrm{mL}$ xanthine oxidase and $100 \mu \mathrm{L}$ of substrate (0.4 $\mathrm{mM}$ xanthine, $0.24 \mathrm{mM}$ nitro blue tetrazolium) are added, and the sample After adding 10ul, it was incubated at $37^{\circ} \mathrm{C}$ for 20 minutes. The absorbance was then measured at $510 \mathrm{~nm}$. The superoxide anion radical scavenging activity was calculated by the following equation: Superoxide anion radical scavenging activity $(\%)=(\mathrm{A}-\mathrm{B}) / \mathrm{A} \times 100$ where $\mathrm{A}$ is the absorbance of the control and $\mathrm{B}$ is the absorbance of the test sample.

\section{Nitric oxide radical (NO') scavenging activity}

Nitric oxide (NO) radical scavenging activity of the Areca nut extracts was measured by the method of Nagata et al. (1999). DAF-2 was dissolved in $550 \mu \mathrm{L}$ of DMSO and mixed with $50 \mathrm{mM}$ phosphate buffer ( $\mathrm{pH}$ 7.4) at a volume ratio of 1:400. Ten microliters of XXX was mixed with $130 \mu \mathrm{L} 50 \mathrm{mM}$ phosphate buffer ( $\mathrm{pH} 7.4$ ) and $10 \mu \mathrm{L} 40 \mathrm{mM}$ SNP (sodium nitroprusside), then $50 \mu \mathrm{L}$ DAF-2 solution was added. The reactions were incubated at room temperature for $10 \mathrm{~min}$, and a fluorescence microplate reader (SPECTRA MAX GEMINI EM, Molecular Devices Corp, USA) was used at an excitation wavelength $485 \mathrm{~nm}$ and emission wavelength $525 \mathrm{~nm}$ to measure the fluorescence intensity of triazolofluorescein produced by the reaction of DAF-2 and NO. NO radical scavenging activity was calculated by the following equation: NO radical scavenging activity $(\%)=(\mathrm{A}-\mathrm{B}) / \mathrm{A} \times 100$ where $\mathrm{A}$ is the absorbance of the control and $\mathrm{B}$ is the absorbance of the test sample. 


\subsection{Assay for the estimation of anti-wrinkling}

\section{Collagenase enzyme inhibition assay}

The collagenase inhibitory effect was measured according to the method proposed by Wünsch \& Heidrich (1963). The substrate solution $(0.25 \mathrm{~mL})$ and the sample, which melts 4-phenylazobenzyloxycarbonyl-Pro-Leu-Gly-D-Arg at a concentration of $0.3 \mathrm{mg} / \mathrm{mL}$ after adding $4 \mathrm{mM} \mathrm{CaCl}_{2}$ in $0.1 \mathrm{M}$ Tris- $\mathrm{HCl}$ buffer ( $\mathrm{pH} 7.5$ ), were mixed at a concentration of $0.1 \mathrm{~mL}$. Then, $0.15 \mathrm{~mL}$ of $0.2 \mathrm{mg} / \mathrm{mL}$ collagenase was added, and the samples were incubated at $37{ }^{\circ} \mathrm{C}$ for $20 \mathrm{~min}$. To stop the reaction, $0.5 \mathrm{~mL}$ of $6 \%$ citric acid was added, followed by addition of $1.5 \mathrm{~mL}$ of ethyl acetate; further, the absorbance was measured at a wavelength of $320 \mathrm{~nm}$. Collagenase inhibition was calculated by the following equation: Collagenase inhibition $(\%)=[1-(\mathrm{B} / \mathrm{A})] \times 100$ where $\mathrm{A}$ is the absorbance of the control and $\mathrm{B}$ is the absorbance of the test sample.

\section{Elastase enzyme inhibition assay}

The effects of elastase inhibitory activity were measured by modifying the method of Kraunsoe et al. (1996). In a 96 well plate, $8 \mu \mathrm{L}$ of sample was mixed with $140 \mu \mathrm{L}$ of $0.2 \mathrm{M}$ Tris- $\mathrm{HCl}$ buffer ( $\mathrm{pH} 8.0$ ), $50 \mu \mathrm{L}$ of $3.2 \mathrm{mM} \mathrm{N}$-succinyl-(Ala) ${ }_{3}$ p-nitroanilide, and $1.4 \mathrm{unit} / \mathrm{mL}$ of porcine pancreas elastase enzyme solution. As a control, $8 \mu \mathrm{L}$ of distilled water was used in place of the sample. All reactions were incubated at $37^{\circ} \mathrm{C}$ for $30 \mathrm{~min}$ and measured at a wavelength of $410 \mathrm{~nm}$. Elastase inhibition was calculated using the following equation: Elastase inhibition $(\%)=100-(\mathrm{B} / \mathrm{A} \times 100)$ where $\mathrm{A}$ is the absorbance of the control and $\mathrm{B}$ is the absorbance of the test sample.

\subsection{Statistical analysis}

All experimental results are shown as mean \pm standard deviation (Mean \pm SD) measured three times. Statistical analysis was performed using the Statistical Package for the Social Sciences (SPSS), and one-way analysis of variance (ANOVA) was performed to test the statistical significance between each experimental group. In cases where differences were observed, the Tukey's test was conducted post-test, with $\mathrm{p}<0.05$ considered statistically significant. The correlation was indicated by the Pearson's correlation coefficient.

\section{Results and discussion}

\subsection{Total Phenolic and Total Flavonoid Contents (TPC, TFC)}

Polyphenol components, including phenolic hydroxy groups, are secondary metabolites commonly contained in plants. They exhibit various physiological activities, including antioxidant activity. Flavonoids are antioxidant substances also widely found in plants (Ham et al., 2018). In this study, total polyphenol content (TPC) and flavonoid content (TFC) of Areca nuts were measured after extraction with various concentrations (0, 40, 80 and 100\%) of $\mathrm{EtOH}$-water and $\mathrm{MeOH}$-water at $100{ }^{\circ} \mathrm{C}$ for $90 \mathrm{~min}$. The TPC and TFC of ethanolic and methanolic extracts from Areca nuts are expressed in terms of the amount of tannic acid and catechin, respectively. The $40 \% \mathrm{EtOH}(34.37 \pm 0.09 \mathrm{mg} \mathrm{TAE} / \mathrm{g})$ and $80 \% \mathrm{MeOH}(29.02 \pm 0.07 \mathrm{mg} \mathrm{TAE} / \mathrm{g})$ extracts had the highest polyphenol content, followed by $80 \% \mathrm{EtOH}(28.97 \pm 0.02 \mathrm{mg}$ TAE/g), 40\% MeOH (22.82 $\pm 0.23 \mathrm{mg} \mathrm{TAE} / \mathrm{g}), 100 \% \mathrm{MeOH}$ $(22.78 \pm 0.17 \mathrm{mg} \mathrm{TAE} / \mathrm{g})$, and hot water $(13.86 \pm 0.07 \mathrm{mg} \mathrm{TAE} / \mathrm{g})$. TFC was also highest in the $40 \% \mathrm{EtOH}(583.12 \pm 3.32 \mathrm{mg} \mathrm{CE} / \mathrm{g})$ and $80 \% \mathrm{MeOH}(549.47 \pm 3.77 \mathrm{mg} \mathrm{CE} / \mathrm{g})$ extracts, and lowest in hot water $(266.69 \pm 0.36 \mathrm{mg} \mathrm{CE} / \mathrm{g})$. These results show that the extraction solvent condition containing the highest amounts of TPC and TFC was $40 \%$ EtOH (Table 1).

\subsection{Assay for the estimation of antioxidant activity}

\section{Phosphomolybdenum antioxidant assay (Total Antioxidant Capacity, TAC)}

The formation of a green colored complex of phosphate and $\mathrm{Mo}(\mathrm{V})$ is the basis of the Fiske-Subbarow spectrophotometric method to determine inorganic phosphate (Prieto et al., 1999). In this study, TAC was measured in Areca nut extracts with various concentrations of EtOH-water and $\mathrm{MeOH}$-water (0, 40, 80, and 100\%). The $\mathrm{RC}_{50}$ value (reduction concentration of extract required to reduce $50 \%$ ) of TAC expressed as $\mathrm{mg} \mathrm{AAE} / \mathrm{g}$ (AAE, ascorbic acid equivalent) showed the highest antioxidant activity in $40 \%$ EtOH $(1156.47 \pm 1.20 \mathrm{mg} \mathrm{AAE} / \mathrm{g})$, followed by $80 \% \mathrm{MeOH}$ (1110.21 $\pm 0.93 \mathrm{mg} \mathrm{AAE} / \mathrm{g})$, and 80\% EtOH (1068.67 $\pm 0.99 \mathrm{mg}$ $\mathrm{AAE} / \mathrm{g}), 100 \% \mathrm{MeOH}(1047.17 \pm 3.01 \mathrm{mg} \mathrm{AAE} / \mathrm{g}), 100 \% \mathrm{EtOH}$ $(948.54 \pm 5.42 \mathrm{mg} \mathrm{AAE} / \mathrm{g}), 40 \% \mathrm{MeOH}(934.60 \pm 9.15 \mathrm{mg} \mathrm{AAE} / \mathrm{g})$, and hot water $(638.35 \pm 0.56 \mathrm{mg} \mathrm{AAE} / \mathrm{g})$ (Table 1$)$. These results

Table 1. Total polyphenol (TPC), Total flavonoid content (TFC), FRAP and total antioxidant capacity (TAC) in water, ethanol and methanol extracts of Areca nut.

\begin{tabular}{lcccc}
\hline \multicolumn{1}{c}{ Sample } & TPC $\left(\mathbf{m g ~ T A E} / \mathbf{g}^{1}\right)$ & TFC $\left(\mathbf{m g ~ C E} / \mathbf{g}^{2}\right)$ & FRAP $\left(\mathbf{m g}\right.$ TE $\left./ \mathbf{g}^{3}\right)$ & TAC $\left(\mathbf{m g ~ A A E} / \mathbf{g}^{4}\right)$ \\
\hline Water & $13.86 \pm 0.07^{\mathrm{a}) 5}$ & $266.69 \pm 0.36^{\mathrm{a}}$ & $1427.85 \pm 3.85^{\mathrm{a}}$ & $638.35 \pm 0.56^{\mathrm{a}}$ \\
$40 \%$ Ethanol & $34.37 \pm 0.09^{\mathrm{e}}$ & $583.12 \pm 3.32^{\mathrm{e}}$ & $1444.81 \pm 2.34^{\mathrm{b}}$ & $1156.47 \pm 1.20^{\mathrm{f}}$ \\
$80 \%$ Ethanol & $28.97 \pm 0.02^{\mathrm{d}}$ & $539.87 \pm 4.53^{\mathrm{d}}$ & $1440.27 \pm 3.58^{\mathrm{ab}}$ & $1068.67 \pm 0.99^{\mathrm{d}}$ \\
$100 \%$ Ethanol & $16.92 \pm 0.09^{\mathrm{b}}$ & $342.43 \pm 1.68^{\mathrm{b}}$ & $1442.00 \pm 1.37^{\mathrm{b}}$ & $948.54 \pm 5.42^{\mathrm{b}}$ \\
$40 \%$ Methanol & $22.82 \pm 0.23^{\mathrm{c}}$ & $431.82 \pm 0.41^{\mathrm{c}}$ & $1438.87 \pm 3.24^{\mathrm{ab}}$ & $934.60 \pm 9.15^{\mathrm{b}}$ \\
$80 \%$ Methanol & $29.02 \pm 0.07^{\mathrm{d}}$ & $549.47 \pm 3.77^{\mathrm{d}}$ & $1443.19 \pm 0.74^{\mathrm{b}}$ & $1110.21 \pm 0.93^{\mathrm{e}}$ \\
$100 \%$ Methanol & $22.78 \pm 0.17^{\mathrm{c}}$ & $443.38 \pm 3.56^{\mathrm{c}}$ & $1445.24 \pm 4.74^{\mathrm{b}}$ & $1047.17 \pm 3.01^{\mathrm{c}}$ \\
\hline
\end{tabular}

${ }^{1}$ TAE: Tannic acid equivalent; ${ }^{2} \mathrm{CE}$ : Catechin equivalent; ${ }^{3} \mathrm{TE}$ : Trolox equivalent; ${ }^{4} \mathrm{AAE}$ : Ascorbic acid equivalent; ${ }^{5}$ Values are Means \pm SD. The different superscripts are significantly different according to ANOVA test $(p<0.05)$. 
confirmed that $40 \% \mathrm{EtOH}$ had the highest antioxidant activity by TAC.

\section{Ferric-Reducing Antioxidant Power (FRAP)}

The FRAP method was designed based on the fact that most antioxidants have reducing power. It is based on the principle that ferric tripyridyltriazine ( $\mathrm{Fe}^{3+}$-TPTZ) complex is reduced to ferrous tripyridyltriazine ( $\mathrm{Fe}^{2+}$-TPTZ) by a reducing agent at low pH (Choi et al., 2009) (Table 1). In this study, FRAP is expressed as $\mathrm{mg}$ TE/g (TE, Trolox equivalent). The FRAP assay results of showed that all the extract concentrations had similar antioxidant activities that ranged from 1445.24 to $1427.85 \mathrm{mg} \mathrm{TE} / \mathrm{g}$.

\section{Peroxynitrite (ONOO-) scavenging activity}

Peroxynitrite (ONOO-) is produced by excessive amounts of $\mathrm{NO}$ and superoxide anions, which can cause protein and lipid peroxidation and central nervous system disease (Kim et al., 2007). In order to prevent or treat various nervous system diseases caused by NO, eliminating ONOO- is useful (Kim et al., 2007). As shown in Figure 2A, the scavenging activities of Areca nut extracts increased $\mathrm{ONOO}^{-}$scavenging activity depending on the ethanolic and methanolic concentration. The $80 \% \mathrm{EtOH}$ extract was found to have a higher scavenging activity (42.76\%) than the L-penicillamine positive control (38.04\%) at the lowest concentration of $25 \mu \mathrm{g} / \mathrm{mL}$.

\subsection{Assay for the estimation of Free Radical}

\section{DPPH radical scavenging activity}

Antioxidant activity using the DPPH radical assay is a general experimental method used for phenolic structures and aromatic amine compounds of various samples (Lee et al., 2004). The free radical scavenging ability determined by DPPH assay is expressed as the $\mathrm{RC}_{50}$ value. The $\mathrm{RC}_{50}$ value showed that the $80 \% \mathrm{MeOH}(373.61 \pm 6.25 \mu \mathrm{g} / \mathrm{mL})$ and $80 \% \mathrm{EtOH}$ $(373.64 \pm 19.47 \mu \mathrm{g} / \mathrm{mL})$ extracts had the highest antioxidant activity, followed by $40 \% \mathrm{MeOH}(407.56 \pm 17.40 \mu \mathrm{g} / \mathrm{mL}), 100 \%$ $\mathrm{MeOH}(448.84 \pm 21.61 \mu \mathrm{g} / \mathrm{mL}), 40 \% \mathrm{EtOH}(461.47 \pm 11.58$ $\mu \mathrm{g} / \mathrm{mL}), 100 \% \mathrm{MeOH}(472.98 \pm 8.43 \mu \mathrm{g} / \mathrm{mL})$, and hot water $(627.86 \pm 9.60 \mu \mathrm{g} / \mathrm{mL})$. DPPH radical scavenging activity of Areca nut extracts was weak when compared with the positive control of L-ascorbic acid $\left(\mathrm{RC}_{50}=188.99 \pm 3.00\right)$ (Table 2$)$. This is in contrast to a previous study where separation and purification of Areca nut extracts showed the presence of excellent DPPH radical scavenging active ingredients (Jeong et al., 2018).

\section{ABTS radical scavenging activity}

ABTS radical scavenging activity is a general experimental method to measure the degree of ABTS scavenging due to the antioxidant power of the various samples by UV-visible absorbance (Lee et al., 2008). The free radical-scavenging ability determined by ABTS is expressed as the $\mathrm{RC}_{50}$ value. ABTS was highest in the $80 \% \mathrm{EtOH}(45.39 \pm 0.16 \mu \mathrm{g} / \mathrm{mL})$ extract, and the lowest in hot water $(82.03 \pm 0.14 \mu \mathrm{g} / \mathrm{mL})$ (Table 2). The ABTS radical scavenging activity results showed relatively higher activity than the DPPH radical scavenging activity. This is because it measures the antioxidant activity of both hydrophilic and hydrophobic samples (Re et al., 1999; Choi \& Shin, 2015; Lee et al., 2016).

\section{Superoxide anion radical scavenging activity (SRSA)}

The superoxide anion radical is the most representative oxygen radical derived from ROS. After the dismutation reaction, it is converted into the highly responsive hydroxyl radical by hydrogen peroxide, thereby damaging biomolecules or inactivating enzymes by directly modifying the protein structure (Lee et al., 2012). The superoxide anion radical scavenging ability (SRSA) is expressed by the $\mathrm{RC}_{50}$ value of superoxide anion capacity. This
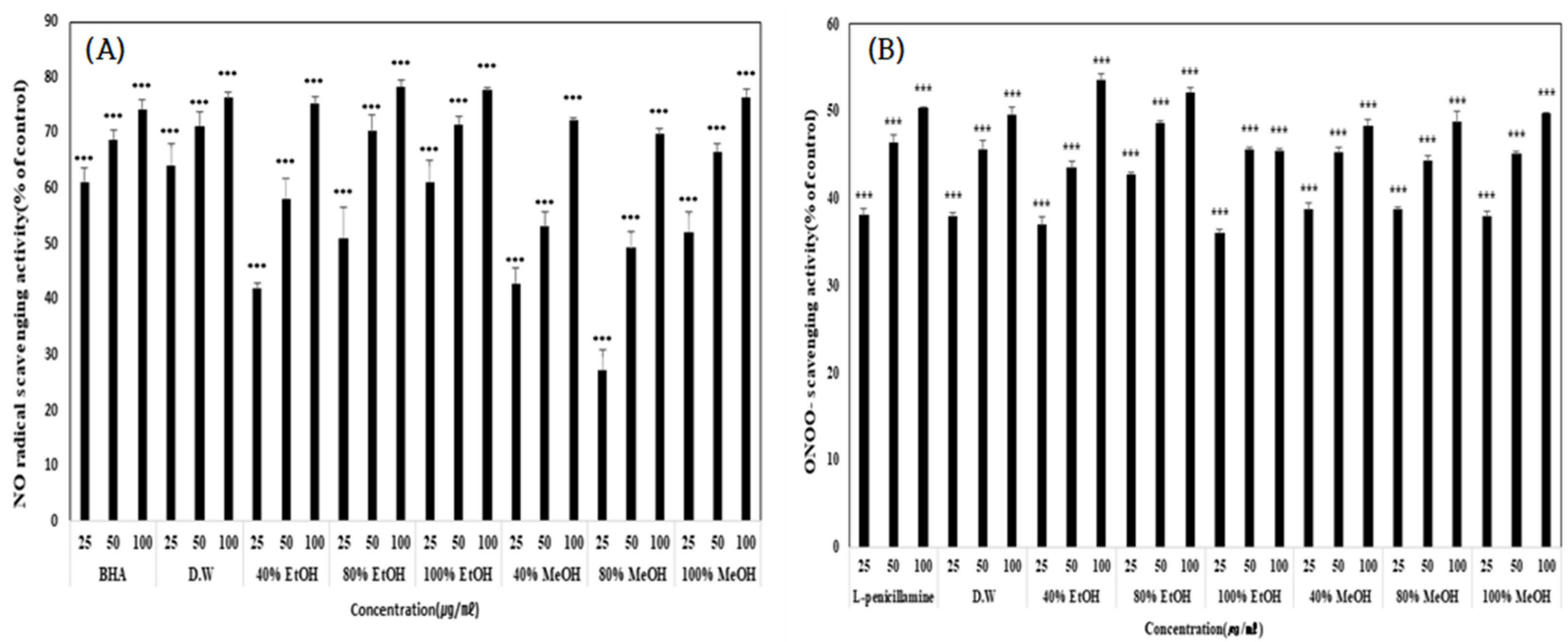

Figure 2. Active nitrogen scavenging activity of Areca nut extract. The values are indicated as mean \pm standard deviation of three independent experiments. ${ }^{* * *} p<0.001$ significance for the comparison with the control. (A) NO radical scavenging activity; (B) ONOO scavenging activity. 
research demonstrated that the $80 \% \mathrm{MeOH}$ extract had the highest scavenging activity with a value of $76.49 \pm 5.74 \mu \mathrm{g} / \mathrm{mL}$, followed by $80 \% \mathrm{EtOH}(76.49 \pm 5.74 \mu \mathrm{g} / \mathrm{mL}), 40 \% \mathrm{MeOH}(81.24$ $\pm 5.94 \mu \mathrm{g} / \mathrm{mL})$, and $100 \% \mathrm{EtOH}(85.62 \pm 0.80 \mu \mathrm{g} / \mathrm{mL})$, The lowest values were given by $100 \% \mathrm{MeOH}(140.57 \pm 2.47 \mu \mathrm{g} / \mathrm{mL})$ and hot water $(141.02 \pm 2.65 \mu \mathrm{g} / \mathrm{mL})$ (Table 2). These results show that the superoxide anion scavenging activity of the Areca nut extracts were superior compared to the L-ascorbic acid positive control.

\section{Nitric oxide radical (NO') scavenging activity}

Nitric oxide (NO) is an RNS and is known to be an important factor in inflammatory reactions. The nitric oxide (NO) scavenging assay measures the fluorescence of DAF-2 produced by inducing NO production using SNP (Lee et al., 2009). As shown in Figure $2 \mathrm{~A}$, the scavenging activities of all extracts showed an increase in NO scavenging activity dependent on concentration. The results of all extract samples were observed to have stronger NO scavenging activity compared to the BHA positive control.

\subsection{Assay for the estimation of anti-wrinkling}

\section{Collagenase enzyme inhibition assay}

Collagen, a major component of the extracellular matrix, is a matrix protein produced by fibroblasts in the skin. The regulation of biosynthesis and degradation of collagen is a core metabolism process of skin aging and skin wrinkle formation (Park et al., 2012). The results of the collagenase enzyme inhibition assay using Areca nut extracts showed better inhibition of collagenase activity than EGCG in all extracts. In particular, $80 \% \mathrm{MeOH}$ extract had the highest collagenase inhibition activity at $200 \mu \mathrm{g} / \mathrm{mL}$, and all extracts except the $200 \mu \mathrm{g} / \mathrm{mL}$ hot water sample showed superior collagenase inhibition activity by more than $60 \%$. The hot water extract showed similar collagenase inhibition activity as the EGCG positive control (Figure 3A).

\section{Elastase enzyme inhibition assay}

Elastase is a matrix protein that helps maintains skin elasticity in the dermis. It is also is involved in the decomposition of elastin,

Table 2. The result of radical scavenging activity in Areca nut.

\begin{tabular}{|c|c|c|c|}
\hline \multirow{2}{*}{ Extract } & \multicolumn{3}{|c|}{$\mathrm{RC}_{50}(\mu \mathrm{g} / \mathrm{mL})$} \\
\hline & $\mathrm{DPPH}^{1}$ & $\mathrm{ABTS}^{2}$ & Superoxide anion $^{3}$ \\
\hline Water & $627.86 \pm 9.60^{c 4}$ & $82.03 \pm 0.14^{\mathrm{f}}$ & $141.02 \pm 2.65^{\mathrm{b}}$ \\
\hline 80\% Ethanol & $373.64 \pm 19.47^{\mathrm{a}}$ & $45.39 \pm 0.16^{\mathrm{a}}$ & $76.49 \pm 5.74^{\mathrm{a}}$ \\
\hline $100 \%$ Ethanol & $448.84 \pm 21.61^{\mathrm{ab}}$ & $59 . .41 \pm 0.10^{\mathrm{d}}$ & $85.62 \pm 0.80^{\mathrm{a}}$ \\
\hline $80 \%$ Methanol & $373.61 \pm 6.25^{\mathrm{a}}$ & $55.10 \pm 0.16^{\mathrm{b}}$ & $70.63 \pm 7.34^{\mathrm{a}}$ \\
\hline $100 \%$ Methanol & $472.98 \pm 8.43^{\mathrm{b}}$ & $69.88 \pm 0.18^{\mathrm{e}}$ & $140.57 \pm 2.47^{\mathrm{b}}$ \\
\hline
\end{tabular}

${ }^{1} \mathrm{DPPH}$ : Amount required for a $50 \%$ reduction of DPPH free radicals; ${ }^{2} \mathrm{ABTS}$ : Amount required for a $50 \%$ reduction of ABTS radicals; ${ }^{3}$ Superoxide anion: Amount required for a $50 \%$ reduction of Superoxide anion radicals; ${ }^{4}$ Values are Means \pm SD. The different superscripts are significantly different according to ANOVA test $(p<0.05)$.
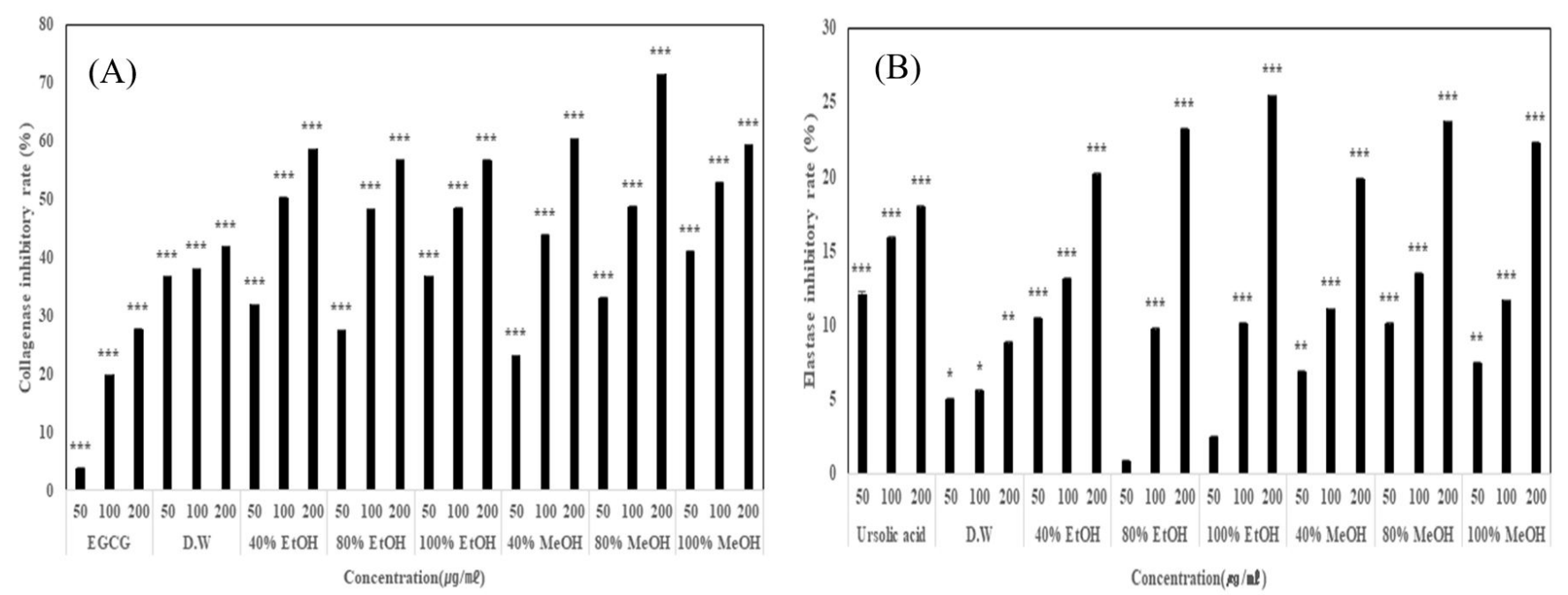

Figure 3. Anti-wrinkle activity of Areca nut extract. The values are indicated as mean \pm standard deviation of three independent experiments. ${ }^{*} p<0.05,{ }^{* *} p<0.01,{ }^{* * *} p<0.001$ significance for comparison with the control. (A) Collagenase inhibition activity; (B) Elastase inhibition activity. 
which causes wrinkles and loss of elasticity of the skin (Choi et al., 2018) (Figure 3B). The $100 \%$ EtOH extract showed excellent Elastase inhibition activity compared to the positive control of $200 \mu \mathrm{g} / \mathrm{mL}$ ursolic acid. All extracts of except hot water showed Elastase inhibition activity greater than $20 \%$ of the control.

\subsection{Correlation between antioxidant activity assay and anti-wrinkling}

The relationship between TPC, TFC, antioxidant assays, and anti-wrinkling was analyzed using regression analysis (correlation coefficient $=R)($ Table 3$)$. TPC of Areca nut extracts showed a high positive correlation with TFC $(R=0.984, p<0.01)$ and total antioxidant capacity $(R=0.788, p<0.01)$. Flavonoids also had a high total antioxidant capacity $(R=0.821, p<0.01)$ and a high positive correlation. This confirms that the higher the total antioxidant capacity was due to TPC and TFC (Figure 4A). Moreover, the
SRSA showed a high positive correlation with DPPH $(R=0.719$, $p<0.01)$, ABTS $(R=0.972, p<0.01)$ and FRAP $(R=0.569$, $p<0.01$ ) activities (Figure 4B). The TPC and TFC of Areca nut extracts demonstrated a weak correlation with their free radical antioxidant activities (DPPH, ABTS, SRSA). However, other studies have reported that the strong antioxidant activities of plant extracts are due to specific bioactive compounds rather than TPC and TFC (Shon et al., 2018; Cho et al., 2016; Kim et al., 2012). The collagenase inhibitory activity was significantly correlated with DPPH $(R=0.891, p<0.01)$, ABTS $(R=0.851, p<0.01)$, and SRSA $(R=0.825, p<0.01)$ in free radical scavenging experiments (Figure $4 \mathrm{C}$ ). In addition, elastase inhibition activity showed a significant correlation with $R=0.336(p<0.05)$ in the FRAP relationship. These results suggest that the strong anti-wrinkling actions of ethanolic and methanolic extracts of Areca nuts may be due to free radical antioxidant activities.
(A)

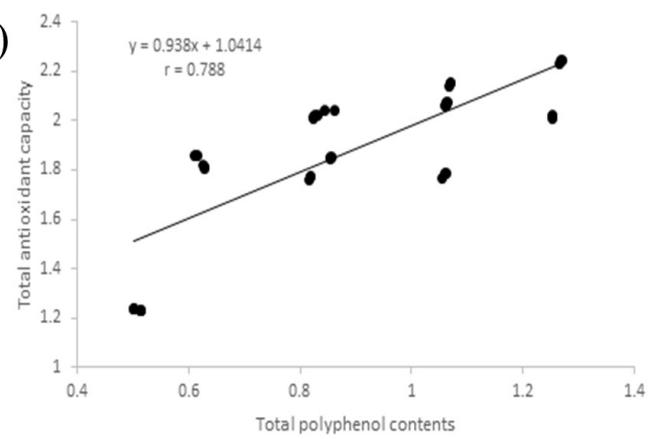

(B)

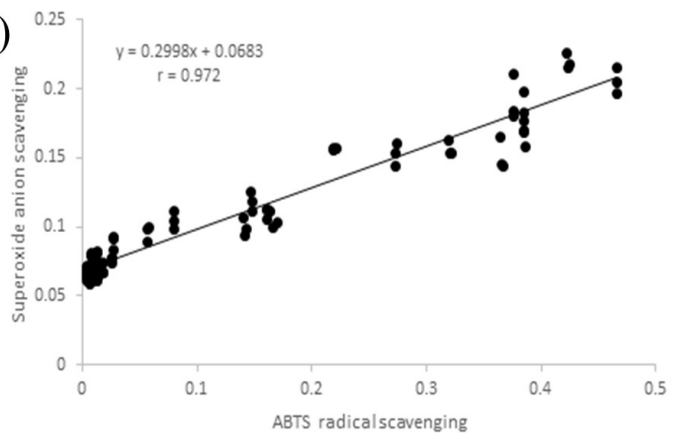

(C)



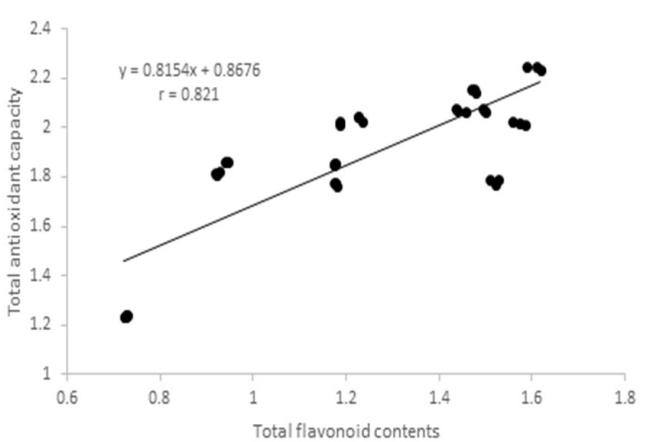
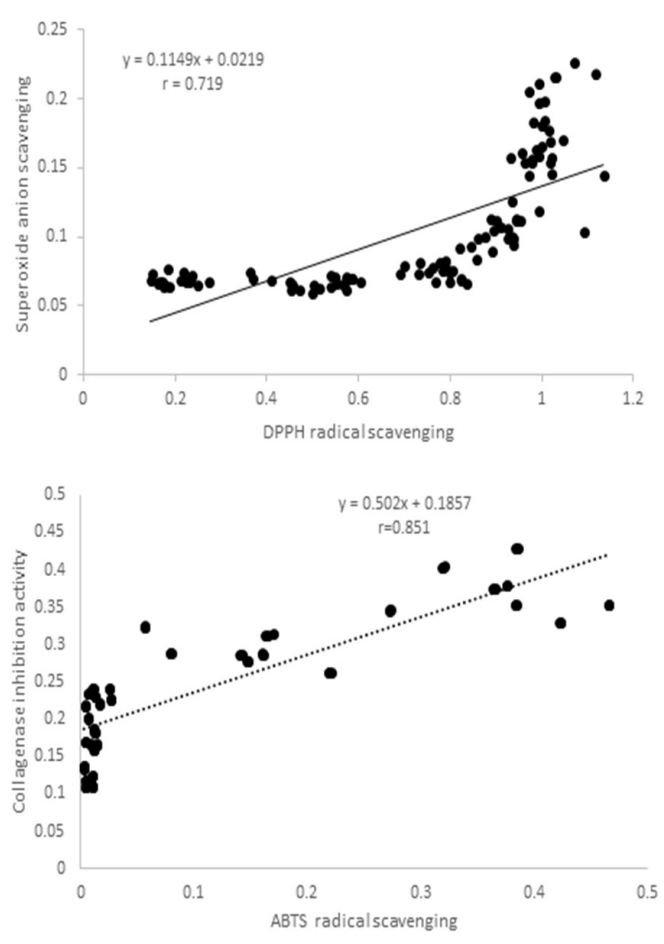

Figure 4. Correlation between antioxidant activity and Areca nut extract. (A) Correlation between total antioxidant capacity, total polyphenol content and total flavonoid content; (B) Correlation between superoxide anion scavenging activity, DPPH radical scavenging activity and ABTS radical scavenging activity; (C) Correlation between collagenase inhibition activity, DPPH radical scavenging activity and ABTS radical scavenging activity. 
Anti-wrinkling and antioxidant activities of Areca nut

Table 3. Correlation coefficient between anti-inflammatory, anti-oxidant, and anti-wrinkle of extracts by Areca nut condition.

\begin{tabular}{|c|c|c|c|c|c|c|c|c|c|}
\hline Factors & $\mathrm{TPC}^{1}$ & TFC $^{2}$ & TAC $^{3}$ & DPPH $^{4}$ & $\mathrm{ABTS}^{5}$ & SRSA $^{6}$ & FRAP $^{7}$ & Collagenase & Elastase \\
\hline TPC & 1 & $0.984^{\star * 8}$ & $0.788^{* *}$ & 0.088 & 0.066 & 0.010 & $0.405^{\star *}$ & 0.038 & 0.062 \\
\hline TFC & & 1 & $0.821^{\star *}$ & 0.102 & 0.065 & 0.008 & $0.453^{\star *}$ & 0.047 & 0.068 \\
\hline DPPH & & & & 1 & $0.713^{* *}$ & $0.719^{* *}$ & 0.242 & $0.891^{\star *}$ & -0.066 \\
\hline ABTS & & & & & 1 & $0.972^{\star *}$ & 0.257 & $0.851^{\star *}$ & 0.048 \\
\hline FRAP & & & & & & & 1 & 0.270 & $0.336^{*}$ \\
\hline Collagenase & & & & & & & & 1 & 0.082 \\
\hline Elastase & & & & & & & & & 1 \\
\hline
\end{tabular}

${ }^{1}$ TPC: Total polyphenol contents; ${ }^{2}$ TFC: Total flavonoid contents; ${ }^{3}$ TAC: Total antioxidant capacity; ${ }^{4}$ DPPH: DPPH radical scavenging activity; ${ }^{5}$ ABTS: ABTS radical scavenging activity; ${ }^{6}$ SRSA: Superoxide anion radical scavenging activity; ${ }^{7}$ FRAP: Ferric-reducing antioxidant power; ${ }^{8}$ Correlation is significantly different at ${ }^{*} \mathrm{p}<0.05$ and ${ }^{* *} \mathrm{p}<0.01$ (Pearson)

\section{Conclusions}

Our research investigated the optimal extraction conditions using the binary solvents $\mathrm{EtOH}$-water and $\mathrm{MeOH}$-water at various concentrations. All extract samples of Areca nut were determined to have antioxidant abilities using TPC, TFC, TAC, DPPH, ABTS, FRAP, $\mathrm{NO}$ radical, $\mathrm{ONOO}^{-}$, collagenase inhibition assays, and elastase inhibition assays. The TPC, TFC, and TAC of the $40 \%$ $\mathrm{EtOH}$ extract was the highest, and antioxidant activity related to free radicals (DPPH, ABTS, SRSA) NO radical scavenging activity, and $\mathrm{ONOO}^{-}$scavenging activity showed the highest scavenging activity in the hot water extract. TAC was confirmed to be highly correlated with the relationship between TPC and TFC and free radical antioxidant activity (DPPH, ABTS, and superoxide anion radicals). ABTS radical scavenging activity and SRSA showed the highest correlation. In addition, collagenase inhibitory activity showed a significant correlation with free radical scavenging activity (DPPH, ABTS, superoxide anion radicals) with an $R$ value ranging from $0.825-0.991(p<0.01)$ (Table 3). Therefore, we determined that the Areca nut extracts demonstrate biological activity, such as free radical antioxidant activity and collagenase inhibition activity, and the optimal extraction condition was $80 \% \mathrm{EtOH}$.

\section{References}

Benzie, I. F., \& Strain, J. J. (1996). The ferric reducing ability of plasma (FRAP) as a measure of "antioxidant power": the FRAP assay. Analytical Biochemistry, 239(1), 70-76. http://dx.doi.org/10.1006/ abio.1996.0292. PMid:8660627.

Chin, J. E., \& Cho, N. C. (2007). The effects of Areca catechu extracts on tyrosinase gene expression in B16 mouse melanoma cells. Korean Journal of Food and Nutrition, 20(2), 240-244.

Cho, M. L., Ko, S. B., Kim, J. M., Lee, O. H., Lee, D. W., \& Kim, J. Y. (2016). Influence of extraction conditions on antioxidant activities and catechin content from bark of Ulmus pumila L. Applied Biological Chemistry, 59(3), 329-336. http://dx.doi.org/10.1007/ s13765-016-0165-8.

Choi, J. H., Kim, Y. S., Lee, K. M., \& Kim, H. J. (2004). The effects of red-ginseng intaking on free radical produced during aerobic exercise in the elderly. Journal of Ginseng Research, 28(1), 27-32. http://dx.doi.org/10.5142/JGR.2004.28.1.027.

Choi, J.-I., Kim, Y.-J., Kim, J.-H., Song, B.-S., Yoon, Y.-H., Byun, M.-W., Kwon, J.-H., Chun, S.-S., \& Lee, J.-W. (2009). Antioxidant activities of the extract fractions from Suaeda japonica. Journal of the Korean Society of Food Science and Nutrition, 38(2), 131-135. http://dx.doi. org/10.3746/jkfn.2009.38.2.131.

Choi, M. H., \& Shin, H. J. (2015). Anti-oxidative and anti-melnogenesis effects of buleberry extract. Asian Journal of Beauty and Cosmetology, 13(2), 261-266.

Choi, M. H., Kim, K. H., \& Yook, H. S. (2018). Antioxidant activity of fermented Kaempferia paruiflora and inhibitory action against tyrosinase and elastase. Journal of the Korean Society of Food Science and Nutrition, 47(11), 1076-1084. http://dx.doi.org/10.3746/ jkfn.2018.47.11.1076.

Fridovich, I. (1970). Quantitative aspects of the production of superoxide anion radical by milk xanthin oxidase. The Journal of Biological Chemistry, 245(16), 4053-4057. PMid:5496991.

Go, Y. J., Kim, Y. E., Kim, H. N., Lee, E. H., Cho, E. B., Sultanov, A., Kwon, S.-I., \& Cho, Y.-J. (2020). Inhibition effect against elastase, collagenase, hyaluronidase and anti-oxidant activity of thinning Green ball apple. Journal of Applied Biological Chemistry, 63(1), 43-50. http://dx.doi.org/10.3839/jabc.2020.006.

Ham, H. N., Shrestha, A. C., Kim, J. E., Lee, T. B., Yoo, B. W., Kim, M. S., Kim, K. S., Cha, J. S., Lee, Y. M., Kim, J. Y., \& Leem, J. Y. (2018). Simultaneous analysis of the compounds of natural cosmetic resources containing Chrysanthemum zawadskii, Perilla frutescens, Rosa multiflora and their anti-oxiative activity. Korean Journal of Pharmacognosy, 49(4), 312-321.

Jeong, Y. H., Kim, S. Y., Jeong, G. H., \& Kim, T. H. (2018). Anti-glyaction and radical scavenging activities of ligustri fructus by extraction method. Korea Journal of Herbology, 33(4), 95-100.

Kim, H. S., Jung, B. O., Lee, S. B., \& Chung, S. J. (2012). Antioxidant and antibacterial activities of pinus koraiensis extracts with chitosan. Journal of Chitin and Chitosan, 17(4), 221-228.

Kim, J. Y., Kim, J. S., Jung, C. S., Jin, C. B., \& Ryu, J. H. (2007). Inhibitory activity of nitric oxide synthase and peroxynitrite scavenging activity of extracts of Perilla frutescens. Korean Journal of Pharmacognosy, 38(2), 170-175.

Kim, M. J., Kim, J. H., Lee, S. H., Cho, E. J., \& Kim, H. Y. (2018). Determination of radical scavenging activity of Aster yomena (Kitam.) 
Honda. Journal of the Korea Academia-Industrial Cooperation Society, 19(9), 402-407.

Kraunsoe, J. A., Claridge, T. D., \& Lowe, G. (1996). Inhibition of human leukocyte and porcine pancreatic elastase by homologues of bovine pancreatic trypsin inhibitor. Biochemistry, 35(28), 9090-9096. http://dx.doi.org/10.1021/bi953013b. PMid:8703913.

Lee, C. H., Yi, H. S., Kim, J. E., Heo, S. K., Cha, C. M., Won, C. W., \& Park, S. D. (2009). Anti-oxidative and anti-inflammatory effect of fractionated extracts of smilacis glabrae rhizoma in human umbilical vein endothelial cell. Korea Journal of Herbology, 24(3), 39-50.

Lee, G. O., You, Y. H., Hwang, K. T., Lee, J. M., Lee, H. J., \& Jun, W. J. (2012). Physicochemical characteristics and antioxidant activities of Luffa cylindrica (L.) Roem. Journal of the Korean Society of Food Science and Nutrition, 41(6), 733-738. http://dx.doi.org/10.3746/ jkfn.2012.41.6.733.

Lee, G. Y., \& Im, D. Y. (2012). Skin-related biological activities of the extract and its fractions from Puerarariae Flos. Journal of the Korean Society of Cosmetology, 18(4), 858-864.

Lee, H.-J., Kim, Y.-A., Park, K.-E., Jung, H.-A., Yoo, J.-S., Ahn, J.-W., Lee, B.-J., \& Seo, Y.-W. (2004). Studies on screening of seaweed extracts for peroxynitrite and DPPH radical scavenging activities. Ocean and Polar Research, 26(1), 59-64. http://dx.doi.org/10.4217/ OPR.2004.26.1.059.

Lee, S. G., Yu, M. H., Lee, S. P., \& Lee, I. S. (2008). Antioxidant activities and induction of apoptosis by methanol extracts from avocado. Journal of the Korean Society of Food Science and Nutrition, 37(3), 269-275. http://dx.doi.org/10.3746/jkfn.2008.37.3.269.

Lee, S. H., Jang, M., \& Kim, G. H. (2016). Antioxidative effects of extracts from different parts of epimedium koreanum nakai. Journal of the Korean Society of Food Science and Nutrition, 45(2), 188-193. http://dx.doi.org/10.3746/jkfn.2016.45.2.188.

Lee, S. H., Kim, S. Y., Son, K. H., Kang, S. J., Chang, S. Y., Park, J. H., \& Lee, K. S. (2001). Isolation and quantitative determination of arecoline from arecae semen. Korean Journal of Pharmacognosy, 32(1), 39-42.

Nagata, N., Momose, K., \& Ishida, Y. (1999). Inhibitory effects of catecholamines and antioxidants on the fluorescence reaction of 4,5-diaminofluorescein, DAF-2, a novel indicator of nitric oxide. Journal of Biochemistry, 125(4), 658-661. http://dx.doi.org/10.1093/ oxfordjournals.jbchem.a022333. PMid:10101276.

Park, C. S., \& Kim, D. H. (2008). Biological activities of extracts from Scutellaria baicalensis Zizyphus jujuba and Atractylodes macrocephala. Korea Journal of Herbology, 23(3), 45-51.
Park, J. Y., Hwang, J. G., Yun, J. K., Han, K. H., Do, E. J., Kim, O. S., \& Kim, M. R. (2012). Effect of Ssanghwa-tang extract on antioxidant and anti-aging enzyme activities. Korea Journal of Herbology, 27(3), 67-74. http://dx.doi.org/10.6116/kjh.2012.27.3.67.

Park, S. B., Lee, D. S., Kang, J. Y., Kim, J. M., Park, S. K., Kang, J. E., Kwon, B. S., Park, S. H., Lee, C. J., Lee, U. K., \& Heo, H. J. (2017). Protective effect on neuronal cells of Orostachys Japonicus A. Berger extrcat against reactive oxygen species-induced neuronal cytotoxicity and active compounds. Korean Journal of Food Science Technology, 49(5), 524-531.

Prieto, P., Pineda, M., \& Aguilar, M. (1999). Spectrophotometric quantitation of antioxidant capacity through the formation of a phosphomolybdenum complex: specific application to the determination of vitamin E. Analytical Biochemistry, 269(2), 337341. http://dx.doi.org/10.1006/abio.1999.4019. PMid:10222007.

Re, R., Pellegrini, N., Proteggente, A., Pannala, A., Yang, M., \& RiceEvans, C. (1999). Antioxidant activity applying an improved ABTS radical cation decolorization assay. Free Radical Biology \& Medicine, 26(9-10), 1231-1237. http://dx.doi.org/10.1016/S0891-5849(98)003153. PMid:10381194.

Shon, H. K., Lee, Y. S., Park, Y. H., Kim, M. J., \& Lee, K. A. (2018). Physicochemical properties of gugija (Lycii fructus) extracts. Korean Journal of Food and Cookery Science, 24(6), 905-911.

Wabaidur, S., Obbed, M., Alothman, Z., Alfaris, N., Badjah-Hadj-Ahmed, A., Siddiqui, M., Altamimi, J., \& Aldayel, T. (2020). Total phenolic acids and flavonoid contents determination in Yemeni honey of various floral sources: Folin-Ciocalteu and spectrophotometric approach. Food Science and Technology. In press. http://dx.doi.org/10.1590/fst.33119.

Wünsch, E., \& Heidrich, H.-G. (1963). Zur quantitativen bestim-mung der kollagenase. Hoppe-Seyler's Zeitschrift für Physiologische Chemie, 333, 149-151. http://dx.doi.org/10.1515/bchm2.1963.333.1.149. PMid:14058277.

Yamaguchi, T., Takamura, H., Matoba, T., \& Terao, J. (1998). HPLC method for evaluation of the free radical-scavenging activity of foods by using 1,1-diphenyl-2-picrylhydrazyl. Bioscience, Biotechnology, and Biochemistry, 62(6), 1201-1204. http://dx.doi.org/10.1271/ bbb.62.1201. PMid:9692204.

Yikmis, S. (2020). Effect of ultrasound on different quality parameters of functional sirkencubin syrup. Food Science and Technology, 40(1), 258-265. http://dx.doi.org/10.1590/fst.40218.

Yun, H. Y., Lim, S. J., Park, H. J., \& Shin, Y. G. (2018). Correlation between antioxidant compounds and activities of 'Hibiscus sabdariffa' teas from different origins. Journal of the East Asian Society of Dietary Life, 28(1), 40-46. http://dx.doi.org/10.17495/easdl.2018.2.28.1.40. 